\title{
Anchor Borrower Programme on Agricultural Commodity Price and Employment Generation in Kebbi State, Nigeria
}

\author{
Saheed, Zakaree S. \\ Alexander, A.A. \\ Isa, Abdulmumin A. \\ Adeneye, O.A.
}

Department of Economics. Faculty of Arts \& Social Sciences,

Nigerian Defence Academy, Kadunda, Nnigeria

Doi: 10.19044/esj.2018.v14n13p240 URL:http://dx.doi.org/10.19044/esj.2018.v14n13p240

\begin{abstract}
Low investment in the agricultural sector, as well as problem of financing are among the major challenges hindering farmers in the rural areas engaging in mechanized farming that might increase food supply, and thereby checking the agricultural commodity prices, and possibly creating more job opportunity in the agricultural sector. In an effort to meet the food supply for the growing population of the country, the government introduced various policies aimed at achieving self-sufficiency in basic food supply, among these policies is the Anchor Borrower Programme. This study examines the impact of Anchor Borrower Program on agricultural commodity price and employment generation in Kebbi state, Nigeria. Data were collected through interview and structured questionnaire administered to a sample of 400 farmers in Argungu L.G.A, of which 360 questionnaire were correctly filled and returned. A multiple regression analysis was used to analyse the data. The results reveal that Anchor Borrower Programmes (ABP) supports for farmer have a positive and statistically significant impact on agricultural commodity price (ACP) and employment generation (EMPG) in agricultural sector in Kebbi state, particularly in Argungu LGA. Based on the findings of this study, it is recommended that anchor borrower programme policy in Nigeria should be encouraged and subjected to periodic review so as to provide more platforms for employment generation and stabilize agricultural commodity price in Kebbi state, particularly in Argungu LGA.
\end{abstract}

Keywords: Anchor Borrower Program, Agricultural Commodity Price, and Employment generation 


\section{Introduction}

The broad spectrum of opportunity in agricultural sector paves way for more attentions of the stakeholders and governments across the globe. The Nigerian government realized that less patronage of locally growing crops may have adverse effect on Nigerian economy in many ways including loss of revenue, high rate of unemployment, inflations, decline in foreign reserve, increase inventory, proliferation of sub-standard crops in the market, price discrimination, problem associated with rural-urban migration, and low productivity among others (Adesina, 2013). This has forced the Nigerian government to place embargo on importation of some agricultural products including, foreign rice, dairy product, and tomatoes, among other commodities through land frontier in order to control or limit the inflow of such commodities (CBN, 2016).

However the low productivity challenges of the Nigerian farmers could be linked to a number of factors, of which agricultural credit facility (loan) remain dominant. Most of the farmers in the rural areas engage in subsistence agriculture and lack sufficient funds to operate, expand their business, or even practice mechanized farming, with modern equipment like plough, tractors and other labour saving devices. Hence, they could not produce enough food to feed the ever growing population of Nigeria. In fact, there is insufficient and limited sources from which funds can be obtained by farmers in the rural areas to improve their productivity (Saheed, 2014).

With a limited supply of food, there could be excess demand, whereby there is tendency for a price to rise as demanders compete against each other, thereby increasing domestic prices. This may eventually lead to high price of food items, which mainly hurt the poor, who spend large shares of their income on staple foods, particularly in Nigeria, where food accounts for more than half of household expenditures. Whereas, any increase in food prices seriously reduce both access to food and the ability to purchase other necessities (Saheed, 2014). This volatility of domestic food prices cause economic uncertainty and may result in lower investment.

Inadequate investment in agribusiness from both the government and private sectors remains one of the major challenges of the sector in achieving its potential, as the main employer and driver of development in the rural region. FAO in Fetcher (2014), estimates that about 1.3 billion people could be employed in agriculture around the world, with about 97 per cent of them in developing countries. Since agricultural produces go beyond subsistence and supplies to the food market, the employment impetus for regional economic development tends to be enormous. However, lack of sufficient financing to the rural farmers, particularly in the study area tends to reduce the farmers' efficiency for optimal operation, which reduces their engagement, particularly during the post-harvest period, when many of the farmers become 
unemployed. According to Nisha, (2008), it is only during the sowing and harvesting seasons that there appear to be near full employment, however, majority of agricultural labour become jobless once harvesting is over. Whereas, an efficient agricultural sector would in no doubt enable a country to generate employment opportunities (Olakundun, Falola, and Ibidun, 2014).

Faced with rising threat of food insecurity, and accelerated increase in food prices, and the consequence social crises, particularly problems of unemployment that might result, the government through its agencies began to respond with a new sense of urgency. In an effort to meet the food supply for the growing population of the country, the government also introduced various policies aimed at achieving self-sufficiency in basic food supply and attainment of food security for the entire population, as well as, encouraging production of improved inputs for the local industries, through increased investment in agricultural business and increasing budget allocation for the agricultural sector. For example, as at December 2017 about $\$ 55$ billion have been so far invested in rice industry through anchor borrower programme of Central Bank of Nigeria (CBN, 2015). This is to provide succor to Nigerian rice farmers in order to meet up some challenges associated with high cost of agricultural input, low output, low income, poor seedling, inadequate fertilizer, low patronage, problem of irrigation, water pumping machine among others.

In furtherance to her past efforts to fight inflation and unemployment, the Central Bank of Nigeria in line with its developmental function established the Anchor Borrowers' Programme (ABP) in year 2015 with a view to collaborate with anchor companies involved in the production and processing of key agricultural commodities. The Programme is targeted toward helping local farmers increase production and supply of feedstock to the processors, reduce importation and conserve Nigeria's external reserves.

Under the Scheme, Anchor firms serve as Off-takers in recognition of their track record and experience in working with out-growers involved in production. The Scheme involves a finance model whereby the anchor firms, CBN, NIRSAL and State Governments organize the out-growers and ensure that they comply with contractual terms thereby reducing the incidence of side-selling. The financing institutions serve as veritable channels for delivering credit to the out-growers.

It has been two years since the inception of the programme, and enough period based on the contractual arrangement, for the beneficiary farmers to be evaluated in order to determine the impact of anchor borrower program (ABP) on the farmers return, as well to examine the impact of ABP on agricultural commodity price and employment generation. It is against this background that this study examines the impact of ABP on agricultural commodity price and employment generation in Argungu local government area, Kebbi state. 
Meanwhile, several studies in the past have examined the impact of agricultural finance on agricultural output/productivity, for instance, Bodiseowei and Tombofa (2016) examine the linkage between agricultural financing, output and macroeconomic growth, Dori (2016) investigated the impact of Central Bank of Nigeria's development finance role on economic growth and development of Nigeria; while, Ekwere, \& Edem, (2014) examined the impact of agricultural credit facility in agricultural production and rural development. Furthermore, Nwankwo (2013) carried out an empirical study on the impact of agricultural co-operative and rural development bank between 1990 and 2010 on agricultural productivity in Nigeria, and Duy, (2012) studied the role of access to credit in rice production efficiency of rural households in the Mekong Delta. However, the study on the impact of $\mathrm{ABP}$ on agricultural commodity price and employment generation has not been well established.

Giving the foregoing, the challenge of this study therefore, is to critically:

i. Examine the impact of Anchor Borrower Programmes (ABP) on the agricultural commodity price.

ii. Investigate the impact of $\mathrm{ABP}$ on employment generation.

To this end, the paper is organized into five sections. Following this introduction is section 2, which focuses on the reviews of relevant literature and theoretical framework. Section 3 discusses the methodology. Section 4 analyses and interprets the data, while section 5 summarises the findings and offer some policy recommendations.

\section{Literature Review}

Anchor borrower program is one of the intervention program of CBN is design to alleviate farmers' challenges, through provision of necessary agricultural input such as farm equipment, fertilizer, water pumping machine, seedling, cash as well as extension services among others. The scheme involves a finance model whereby the anchor firms, CBN, NIRSAL and State Governments organize the out-growers and ensure that they comply with contractual terms thereby reducing the incidence of side-selling. The financing institutions will serve as veritable channels for delivering credit to the outgrowers. The stakeholders were drawn from government agency, farmers association, bank of agricultural and individual farmers while, CBN is to service as coordinate organ and financial intermediation.

Theoretically, financial intermediation typically facilitates the channeling of funds between lenders and borrowers. That is, savers (lenders) give funds to an intermediary institution (such as a bank), and that institution gives those funds to spenders i.e borrowers (Infinite Financial Intermediation, 2015). According to classical and neoclassical economics, as well as most mainstream economics, a financial intermediary is typically a bank that 
consolidates deposits and uses the funds to transform them into loans. Through the process of financial intermediation, certain assets or liabilities are transformed into different assets or liabilities (Pierre, 2001; Global Shadow Banking Monitoring Report, 2013). That is, savers (lenders) give funds to an intermediary institution (such as a bank), and that institution gives those funds to spenders (borrowers). This may be in the form of loans or mortgages. Alternatively, they may lend the money directly via the financial markets, and eliminate the financial intermediary, which is known as financial disintermediation. Subsequently, in the case rice farmer in the study area are the spender (borrower)

Furthermore, current theories of the economic role of financial intermediaries build on the economics of imperfect information that began to emerge during the 1970s with the seminal contributions of Spence (1973) and Rothschild and Stiglitz (1976). Financial intermediaries exist because they can reduce information and transaction costs that arise from an information asymmetry between borrowers and lenders. Financial intermediaries thus assist the efficient functioning of markets, and any factors that affect the amount of credit channeled through financial intermediaries can have significant macroeconomic effects.

There are two strands in the literature that formally explain the existence of financial intermediaries. The first strand emphasizes financial intermediaries' provision of liquidity. The second strand focuses on financial intermediaries' ability to transform the risk characteristics of assets. In both cases, financial intermediation can reduce the cost of channeling funds between borrowers and lenders, leading to a more efficient allocation of resources.

Williamson (1986) developed a model of credit rationing where borrowers are subject to a moral hazard problem. Borrowers are identical ex ante, but some receive loans and others do not. A borrower and lender are asymmetrically informed ex post about the return on the borrower's investment project, and the borrower will have an incentive to falsely default on the loan. Costly monitoring by lenders of borrowers together with largescale investment projects imply that there exist increasing returns to scale in lending and borrowing which can be exploited by financial intermediaries. The optimal contract between a lender and a borrower is a debt contract and the lender only monitors in the event of default.

The quantity theory of credit worked upon by Werner (1993) and adopted by Nnamocha and Eke (2015) distinguish between money used for GDP-transaction and non-GDP transaction. They both agreed that banks also function as creators of new money through process of lending, which is required to increase transactions in economic activity. The effect of bank lending or credit depends on whether it is used for productive or unproductive 
activities. Bank credits used for productive purposes like the Agricultural Borrower Programmes funds to farmers in Kebbi State aims at income growth, employment generation, and it is sustainable. However, credits for unproductive purposes like credit for consumption or asset transaction, according to Werner (1993), are directed towards capital gain and is unsustainable.

From another angle, the Monetary Circuit Theory (MCT), which holds that money is endogenously created by the banking sectors rather than exogenously by the government through the Central bank's lending (Graziani, 1989), focuses on two main cardinal points, that is, the stock and the economic transactions. While the stock is seen as the initial loan advanced by the banks to the farmers, the economic transaction is seen as productive activities initiated by lending from banks over a given period transaction (Keen, 2009, in Ayodeji \& John, 2014). In the context of this study, the stock is therefore seen as the initial loan by the Agricultural Borrower Programme to the farmers, while the economic transaction is seen as the effect of the economic transaction which reflects in agricultural commodity prices and employment generation.

Shoaib, Luan, xiao, Sanaullah, Qurat, Abdul and Moula (2016) investigate the significance of agricultural finance on agricultural and rural development of Pakistan. Primary data was collected from Borrowers and None Borrowers of agricultural finance from district Qambar Shahdadkot, Sindh Province of Pakistan. Borrowers of agricultural finance include formal and non-formal sources of finance. The results shows that the total revenue of agricultural finance borrowers was 76000 rupees while the non-borrowers agricultural revenue was 61750 rupees and the variable cost for agricultural finance borrowers was a little bit high then non borrowers as 41652 and 34342 rupees respectively. The variation was due fund available to the farmer. However, based on the peculiar of each nation the result may be not the same if tested elsewhere.

Kiragu (2015) examines the relationship between agricultural financing and productivity of Dairy farming in Central Kenya. The study adopted secondary data. A census survey was undertaken using Time series data for the period 1981- 2013. Regression model was developed to quantify the impact of credit, number of dairy cattle and number of cooperatives on milk yield. The findings of the study revealed that there is a positive relationship between agricultural financing and productivity of dairy farming in Central Kenya.

Ahmad, Imtiaz, and Ijaz (2014) examine socio-economic effect of loan on farmers' daily life in Pakistan. Quantitative research design was used for data collection. Universe of the present study consisted of all farmers who were taking loan from ZTBL microfinance house. A sample of 120 
respondents was selected with the help of systematic random sampling. Interview schedule was used as a tool of data collection. The findings of the study shown that access to microfinance have significant impact on improving the productivity of farmers and contributing to uplifting the livelihoods. It also increases the production through which farmer is able to reinvest its surplus amount to gain maximum profit. However, the study did not identify what measure used for farmers daily life.

Friday, Ogbechie, Kelikume and Ikpesu (2016) examine the impact of the credit supply, and various commercial bank loan schemes on agricultural sector production in Nigeria. Using vector autoregressive (VAR) approach, the findings of the study revealed that Agricultural Credit Guaranty Scheme Fund does not have positive impact agricultural sector production while commercial loans to agricultural sector had a positive impact on agricultural production. This difference in the impact of fund could be attributed to terms of lending. Noticeable, this study did not consider the direct impact of credit supply to farmers who are the last resort beneficiary.

Dori (2016) examines the effects of Central Bank of Nigeria's development finance role on economic growth and development of the Nigerian economy, with special reference to Central Bank of Nigeria's Credit Schemes. Descriptive survey method was adopted; The findings from the study revealed that Central Bank of Nigeria's Credit schemes have increased the level of credit inflow which increased the level of productivity, employment generation, agricultural output, domestic trade, rural development, exports, foreign earnings and import substitution in Nigeria and subsequently, this have improved the level of economic growth and development of the Nigerian economy. The generality of this finding is may produce different result if target a particular farmers output, therefore by aggregate all the sector is fault approach.

Abu and Rohana (2016) examine the impact of Commercial Agricultural Credit Scheme (NSCACS) on poverty alleviation in Niger State, Nigeria. The study adopted content analysis approach, using survey literature. The findings of the study revealed that there is an increase in the lending capacity of CACS without a corresponding increase in poverty alleviation. Using content analysis to study a dynamic situation such experience in rice farming production is not sufficient methodology.

Bodiseowei, and Tombofa (2016) examine the effect of agricultural financing on agricultural output and macroeconomic output in the Nigerian economy. The Error Correction results from the analysis of time series data provided empirical evidence that there is a positive relationship between agricultural credit and agricultural output. Agricultural credit also had a positive effect on real GDP growth over the period of the study. However, credit default by borrowers is a serious menace which reduces the confidence 
of lenders. By extension there is need to adopt primary data to ascertain what exist presently.

\subsection{Research Methodology}

This section discusses the research design, population of the study, sampling techniques and sample size, source and techniques of data collection, model specification and method of data analysis.

\subsection{Research Design}

The study adopts a survey research design; specifically both quantitative and qualitative mixed approach research design was employed. The study collected cross-sectional data from the study areas and analysis in order to describe and interprets the results. Primary and secondary data were sourced for the study. Primary data was sourced via questionnaire instrument, informant interview, and focus group discussion. While, secondary information was sourced from various publications of CBN. The quantitative data were analyzed using the descriptive statistics and multiple regression analysis. Thereafter, both quantitative and qualitative data are triangulated for better research results with the help of SPSS version 20 software package.

\subsection{Population and Sample}

The target population for this study comprises the 78000 rice farmers who have benefited from ABP of CBN in Argungu local government areas; the choice of this Argungu area is based on the large numbers of beneficiary of ABP as documented by CBN. The sampling frame used in this study was extracted from $\mathrm{CBN}$ publication on ABP, 2016. However, due to the large numbers of the farmer so far benefited from $\mathrm{ABP}$ for the purpose of realistic and thorough research, simple size determination was adopted for effective field work coverage. Using, Taro Yamen (1971) formula, presented as follows; $\mathrm{S}=\frac{N}{1+N\left(M E^{2}\right)}$

Where: 's' is the desired sample; ' $N$ ' is the population size; and ' $M E$ ' is the margin of error allowed in determine the sample size:

$\mathrm{s}=\frac{78000}{1+78000\left(0.05^{2}\right)}=\mathrm{s}=\frac{78000}{1+78000(0.0025)}=397.9$ approximately, 398 .

The study sample size is 398 respondents as shown above, thereafter;

\subsection{Model Specification}

In order to examine the impact of anchor borrower program on agricultural commodity price and employment generation in Kebbi state, Nigeria. The mathematical model is specified as follows; 
$\mathrm{ACP}=f(\mathrm{ABP}, \mathrm{RO}, \mathrm{PI}, \mathrm{EMPG})$

Equation 1 can be rewritten in a stochastic format thus:

Similarly,

$$
\mathrm{ACP}=\beta_{0}+\beta_{1} \mathrm{ABP}+\beta_{2} \mathrm{RO}+\beta_{3} \mathrm{PI}+\beta_{4} \mathrm{EMPG}+\varepsilon \ldots \ldots \ldots \ldots \ldots .2
$$

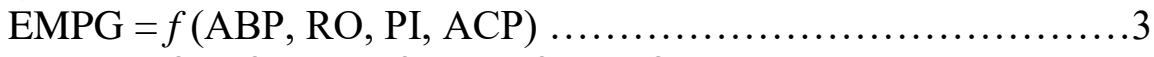

$\mathrm{EMPG}=\beta_{0}+\beta_{1} \mathrm{ABP}+\beta_{2} \mathrm{RO}+\beta_{3} \mathrm{PI}+\beta_{4} \mathrm{ACP}+\varepsilon \ldots \ldots \ldots \ldots \ldots . .4$

Where:

$\mathrm{ACP}=$ Agriculture commodity price defined as the price that consumer are willing and

able to pay for agricultural commodity (rice commodity) in the study area, measured by the average current prices of a bag of rice in the open market within the study area.

EMPG $=$ Employment generation, defined as the creation of new job attributed to anchor

borrower program within the study area.

$\mathrm{ABP}=$ Anchor borrower programme, that is, intervention program of CBN design to

provide support to small scale farmers. This is measured by the amount of money plus other equipment given to individual rice farmer in the understudy area.

$\mathrm{RO}=$ Rice output; this is the numbers of rice bag farmer produce with a given unit of input.

PI = Rice farmers' personal income; is rice farmer personal income this is income

accrued to farmer at the end of farming season. According to Freshwater, (2009) aggregate farm income is the standard measure of farm household economic well-being.

$\alpha=$ intercept $\beta_{1}, \beta_{2}$ and $\beta_{2}$ are the parameters estimate

$\varepsilon=$ Measurement error.

\subsection{Results and Discussions}

This section presents empirical analysis of returned data, results and discussions.

Objective one: Impact of Anchor Borrower Programmes (ABP) on agricultural commodity price (ACP) in Kebbi State of Nigeria 
Table 1a.

Model Summary

\begin{tabular}{|c|c|c|c|c|}
\hline Model & R & R Square & Adjusted R Square & Std. Error of the Estimate \\
\hline 1 & $.845^{\mathrm{a}}$ & .714 & .711 & .46021 \\
\hline
\end{tabular}

a. Predictors: (Constant), EMPG, PI, RO, ABP

Source: SPSS Statistics 20 Output from study data, 2017

The table 1a presents the model summary of the analysis. The $\mathrm{R}^{2}$ of 0.714 calculated points to the fact that about 71 percent increase in the agricultural commodity price (ACP) in Kebbi State of Nigeria is explained by the regressors. That is, $71 \%$ variation in agricultural commodity price (ACP) can be explained by changes in the Anchor Borrower Programmes (ABP) and other explanatory variables, while the other $29 \%$ variation can be explained by other factors outside this model.

Table $1 \mathrm{~b}$.

Coefficientsa

\begin{tabular}{|c|c|c|c|c|c|c|}
\hline & \multirow[t]{2}{*}{ Model } & \multicolumn{2}{|c|}{$\begin{array}{c}\text { Unstandardized } \\
\text { Coefficients }\end{array}$} & $\begin{array}{l}\text { Standardized } \\
\text { Coefficients } \\
\end{array}$ & \multirow[t]{2}{*}{$\mathrm{t}$} & \multirow[t]{2}{*}{ Sig. } \\
\hline & & B & Std. Error & Beta & & \\
\hline \multirow{5}{*}{1} & (Constant) & .704 & .202 & & 3.495 & .001 \\
\hline & $\mathrm{ABP}$ & .727 & .063 & .896 & 11.612 & .000 \\
\hline & RO & -.129 & .081 & -.113 & -1.600 & .111 \\
\hline & PI & .077 & .052 & .100 & 1.485 & .139 \\
\hline & EMPG & -.057 & .085 & -.047 & -.675 & .500 \\
\hline
\end{tabular}

a. Dependent Variable: ACP

Source: SPSS Statistics 20 Output from study data, 2017

Table $1 \mathrm{~b}$ presents the coefficients of the explanatory variables. The results show a positive and statistically significant impact of ABP on ACP. With a coefficient of 0.727 , it indicates that one percent increase in ABP support to the rural farmers lead to $0.73 \%$ increase in agricultural commodity price (ACP). More so, rice output shows a negative and statistically insignificant impact on ACP. With a coefficient of -0.129 , it implies that one percent increase in rice output (RO) tends to effect a $0.13 \%$ decreases in agricultural commodity price (ACP). This implies that with an increase in total output of rice production, it increases the total supply in the market, thereby forcing the price to fall.

In the same vein, the farmers' personal income shows a positive, but statistically insignificant impact on ACP. By implication, with a coefficient of 0.077 , one percent increase in farmer personal income (PI) effect a $0.08 \%$ increase in agricultural commodity price (ACP). 
Furthermore, employment shows a negative but statistically insignificant impact on ACP. With a coefficient of -0.057 , it implies that one percent increase in employment (EMPG) lead to $0.057 \%$ decrease in agricultural commodity price (ACP). With an increase in agricultural labour working in the farm, there is tendency for the total output to increase which will increase rice supply to the market, thereby forcing the price to fall.

All the predictors standard error values with exception of $\mathrm{RO}$ and EMPG is less than beta values, likewise the t-test value of ABP and PI is greater than standardized coefficients (beta) value with the ABP Sig value of 0.000 less than 0.05 significant level at $95 \%$ confident level suggests that anchor borrower programmes (ABP) have statistically significant positive impact on the agricultural commodity price (ACP). Other variables RO, PI and EMPG in the model with the Sig value at $95 \%$ confident level. The policy implication of this result is that anchor borrower programmes (ABP) of central bank of Nigeria have the capability of stabilize agricultural commodity price if sustained in the study area.

\section{Objective of Two: Impact of Anchor Borrower Programmes (ABP) on Employment Generation.}

Table 2a.

Model Summary

\begin{tabular}{|c|r|r|r|r|}
\hline Model & \multicolumn{1}{|c|}{$\mathrm{R}$} & \multicolumn{1}{|c|}{ R Square } & Adjusted R Square & \multicolumn{1}{c|}{ Std. Error of the Estimate } \\
\hline 1 & $.913^{\mathrm{a}}$ & .834 & .832 & .28833 \\
\hline
\end{tabular}

a. Predictors: (Constant), ACP, RO, PI, ABP

Source: SPSS Statistics 20 Output from study data, 2017

The table 2a presents the model summary. The $\mathrm{R}^{2}$ is robust enough and showing a good at 0.834 . With a coefficient of determination indicating that about 83 percent employment generation (EMPG) in the agricultural sector un Kebbi State of Nigeria is explained by the regressors. That is, $83 \%$ variation in employment generation (EMPG) can be explained by increase in the Anchor Borrower Programmes (ABP) support to farmers and other explanatory variables, while the other $17 \%$ variance can be explained by other factors outside this model. 
Table 2b.

Coefficients ${ }^{\mathrm{a}}$

\begin{tabular}{|c|c|c|c|c|c|c|}
\hline & \multirow[t]{2}{*}{ Model } & \multicolumn{2}{|c|}{$\begin{array}{c}\text { Unstandardized } \\
\text { Coefficients } \\
\end{array}$} & \multirow{2}{*}{$\begin{array}{c}\text { Standardized } \\
\text { Coefficients } \\
\text { Beta }\end{array}$} & \multirow[t]{2}{*}{$\mathrm{T}$} & \multirow[t]{2}{*}{ Sig. } \\
\hline & & $\mathrm{B}$ & Std. Error & & & \\
\hline \multirow{5}{*}{1} & (Constant) & 1.288 & .109 & & 11.844 & .000 \\
\hline & $\mathrm{ABP}$ & .234 & .044 & .351 & 5.274 & .000 \\
\hline & RO & .369 & .047 & .395 & 7.888 & .000 \\
\hline & PI & .146 & .032 & .228 & 4.572 & .000 \\
\hline & $\mathrm{ACP}$ & -.022 & .033 & -.027 & -.675 & .500 \\
\hline
\end{tabular}

a. Dependent Variable: EMPG

Source: SPSS Statistics 20 Output from study data, 2017

Table $2 b$ present the coefficients of the explanatory variables. The results show that the Anchor Borrowing programme shows a positive and statistically significant impact on employment generation in the study area. With a coefficient of 0.234 , it implies that one percent increase anchor borrower programmes (ABP) support to farmers tends to effects a $0.2 \%$ increase in employment generation (EMPG) in the agricultural sector in the study area. Increase in ABP support to the farmers will enable to expand their production, which may requires more inputs including labour, thereby creating more employment opportunities in the agricultural sector.

The result also shows that rice output has a positive and statistically significant impact on employment generation in agricultural sector. With a coefficient of 0.369 , it indicates that one percent increase in rice output (RO) effect a $0.37 \%$ increases in employment generation (EMPG). This can be attributed to the fact that increases in rice output requires more input inform of manpower, hence generate more employment opportunities in the sector.

In the same vein, the result further reveals that personal income of the farmers has a positive and statistically significant impact on employment generation in the agricultural sector. With a coefficient of 0.146 implying that one percent increases in farmer personal income (PI) effect a $0.15 \%$ increases in employment generation (EMPG) in the agricultural sectors in the study area. With increase in personal income, it encourages the farmer to expand his operation hence he may have to employ more labour.

The results further reveal that ACP has a negative but insignificant impact on employment generation in the agricultural sector. It has a coefficient of -0.022 , indicating that one percent increase in agricultural commodity price (ACP) will tend to decrease the chance of employment generation (EMPG) in the agricultural sector by $0.02 \%$. With increase in agricultural commodity prices, it tends to slows down demand for the agricultural commodities, and 
this may discourage the farmers from investing more, hence reducing inputs including agricultural labour.

Table 2c.

ANOVA a

\begin{tabular}{|c|c|c|c|c|c|}
\hline Model & Sum of Squares & Df & Mean Square & $\mathrm{F}$ & Sig. \\
\hline Regression & 147.987 & 4 & 36.997 & 445.024 & $.000^{\mathrm{b}}$ \\
\hline 1 Residual & 29.513 & 355 & .083 & & \\
\hline Total & 177.500 & 359 & & & \\
\hline
\end{tabular}

a. Dependent Variable: EMPG

b. Predictors: (Constant), ACP, RO, PI, ABP

Source: SPSS Statistics 20 Output from study data, 2017

In table 2c ANOVA table the F-test explained the joint impact of the predictor variables on the dependent variable. The F-value of 445.024 with Sig-value of 0.000 indicated that the overall model is statistical significant in explaining the relationship between the dependent and independent variables.

\section{Conclusion}

Based on the objectives of the study to examine the impact of anchor borrower programmes of on the agricultural commodity price and employment generation in Argungu local government area of Kebbi state, and the analysis carried on the primary data collected from the sample of 360 respondents, the results obtained show that Anchor Borrower Programmes (ABP) have a positive and statistically significant impact on agricultural commodity prices. With one percent increase ABP, there is likely to be an increase of about $0.73 \%$ in agricultural commodity price (ACP). The results show further reveals that $\mathrm{ABP}$ shows a positive and statistically significant impact on employment generation in the agricultural sector. The result shows that one percent increase in ABP support for rice farmers in the study area tends to increase employment generation (EMPG) opportunities by about $0.23 \%$. Thus, these findings are line with that of Dori (2016) who observed that that Central Bank of Nigeria's Credit schemes increases the level of credit inflow which increased the level of productivity, employment generation, agricultural output. Based on the findings, the study therefore recommends that anchor borrower programme policy in Nigeria should be encouraged and subjected to periodic review so as to provide more platforms for employment generation and stabilize agricultural commodity price.

\section{References:}

1. Abu, I \& Rohana, Y. (2016).Commercial agriculture credit scheme: An agenda setting for poverty alleviation in Nigeria: challenges and 
Prospects. Journal of education and social sciences, 4 (2016): ISSN 2289-9855

2. Adesina, A (2013). Rice Consumption Importation in Nigeria, no solution and insight. Publication of vanguard Nigeria newspaper. http://www.vanguardngr.com/2013/12/rice-consumption-

importation-nigeria-solution-sight/

3. Adolphus, J.T \& Peterside, D.B. (2014). Analysis of the role of banks in financing the agriculture and manufacturing sectors in Nigeria. International journal of research in business management, 2(2):9-22. $\operatorname{ISSN}(E):$ 2321-886X; $\operatorname{ISSN}(P):$ 2347-4572.

4. Ahmad, S., Imtiaz, A. W \& Ijaz,M.(2014). Socio-economic effects of microfinance on agricultural sector: An analysis of farmer's standard of life in Multan. International review of management and business research, 3(3):2014

5. Akande,T (2001). An Overview Of The Nigerian Rice Economy. Nigerian Institute of Social and Economic Research (NISER), unep.ch/etu/etp/events/.../pps_nigeria.pdf.

6. Anigbogu,T. U., Onugu, C.U., Igboka, G. E \& Okoli, M.I. (2015). Factors affecting cooperative farmers access to agricultural credit from microfinance banks in Awka North L.G.A of Anambra State, Nigeria. International journal of economics, commerce and management United Kingdom 3(11:1114 http://ijecm.co.uk/ ISSN 23480386.

7. Aschale,D.S., Hilhorst,D \& Pankhurst,A.(2012). The differential impact of microcredit on rural livelihoods: case study from Ethiopia. International journal of development and sustainability, 1(3): www.isdsnet.com/ijds

8. Ayaz, S. and Hussain, Z. (2011). Impact of institutional credit on production efficiency of farming sector: A case study of Faisalabad. Pakistan economic and social review. 49(2):149-162.

9. Ayodeji, A.A. \& John, A.T. (2014). Deposit money banks' financing of small scale business and Nigerian economic growth, KASU Journal of Accounting Research and Practice, 3(2),63-74.

10. Bodiseowei, C.O \& Tombofa, S.S.(2016). An econometric analysis of the linkage between agricultural financing, output and macroeconomic growth. International journal European 10(1):1-16

11. Dori, N.A.S. (2016). The impact of central bank of Nigeria's development finance role on economic growth and development of Nigeria. Inter. J. Polit. Sci. Develop. 4(3):75-81

12. Duy, V.Q. (2012). The role of access to credit in rice production efficiency of rural households in the Mekong delta, vietnam. CAS Discussion paper No 84. 
13. Dyer, $C$ (2007). A suffolk farmer in the fifteenth century. Agricultural History Review.55 (1):1-22. JSTOR 40276126.

14. Ehinomen, C \& Akorah, C. C (2012). The impact of monetary policy on agricultural development in Nigeria (1970-2010). Journal of Humanities and Social Science (JHSS) 5(5):13-25.

15. Ekwere, G. E. \& Edem, I. D.(2014). Evaluation of agricultural credit facility in agricultural production and rural development. Global Journal of human-social science: B Geography, Geo-Sciences, Environmental Disaster Management 14(3).

16. Fetcher, J. (2012). Agriculture and employment. Key position paper, Sector and Policy Division Agriculture and Natural Resources.

17. Freshwater, D. (2007). Measuring farm net income to better achieve policy objectives. unpublished paper prepared for the agriculture Canada and Statistics Canada Joint Workshop on Farm Income Measurement Ottawa Canada. March, 2007.

18. Friday, O. A., Ogbechie,C., Kelikume,I \& Ikpesu,F. (2016).Credit supply and agricultural production in Nigeria: a vector autoregressive (var) approach. Journal of economics and sustainable development 7(2)

19. Graziani, A. (1989). The theory of money circuit. ISBN 978090216939-5

20. Institute for Policy Studies. (2013). Financial intermediaries. A glossary of climate finance terms, IPS, Washington DC.

21. Keen, S. (2009). The political economy of money circuits: Tradition and change in post Keynesian economics. London: Palgrave Macmillan

22. Kiragu, B.M. (2015). The relationship between agricultural financing and productivity of dairy farming in Central Kenya. A Thesis Submitted to University of Nairobi 2015.

23. Nisha, N. (2014). Woman labour in agriculture-An economic analysis. A Thesis Submitted to University of Agricultural Sciences, Dharwad.

24. Nnamocha, P.N. \& Eke, C.N. (2015). Bank credit and agricultural output in Nigeria (1970-2013): An Error Correction Model (ECM) approach, British Journal of Economics, Management \& Trade, 10(2), 1-12

25. Nwankwo, O (2013). Agricultural financing in Nigeria: an empirical study of Nigerian agricultural co-operative and rural development bank (NACRDB): 1990-2010. Journal of Management Research 5(2): ISSN 1941-899X.

26. Olakundun, A.M., Falola, B.H., \& Ibidun, A.S. (2014). Agro-business as a remedy for youth employment towards the achievement of sustainable development in Nigeria: Comparative perspective from the 
Kwara state agro-business economy. Journal of Economics and Sustainable Development, 5(3), 46-57.

27. Rice web. (2001). Analysis of rice farming system in Ogun state and its implications for extension programmes 1(1):1-102. University of Agriculture, Abeokuta, Nigeria.

28. Rothschild, M. \& Stiglitz, J. E. (1976). Equilibrium in competitive insurance markets: an essay on the economics of imperfect information. Quarterly Journal of Economics 9(5): 629-649.

29. Saheed, Z.S. (2014). Impact of Agricultural Credit Guarantee Scheme Fund (ACGSF) on domestic food supply in Nigeria, British Journal of Economics, Management \& Trade, 4 (8), 1273 - 1284.

30. Shoaib, A.W., Luan, J., Xiao, S., Sanaullah, N., Qurat Ul, A., Abdul, $\mathrm{R} \&$ Moula, B. (2016).Significance of agricultural finance in agricultural and rural development of Pakistan "a case study of Qambar Shahdadkot District". European Journal of Business and Management 8(16): 16 .

31. Sial.M.H, Awan.M.S, \& Waqas.M. (2011). Role of institutional credit on agricultural production: a time series analysis of Pakistan, International journal of economics and finance, 3(2).

32. Spence, M. (1973). Job market signaling. Quarterly Journal of Economics 87, 355-374.

33. Uche, N; Taylor, J \& Trego, R. (2016). Nigerian grain and feed annual report. usda foreign agricultural service. global agricultural information network.

34. Werner, R.T. (1993). Towards a quantity theory of disaggregated credit and international capital flows. A Paper Presented at the Royal economic Society Annual Conference in New York; 1993.

35. Weisbrod, B. \& Hansen, W. L. (1968). An Income-net worth approach to measuring economic welfare. American economic review. 58(5): 1315-1329.

36. Williamson, S. D. (1986). Costly monitoring, financial intermediation, and equilibrium credit rationing. Journal of Monetary Economics 18(1):159-179.

37. World Bank. (2009). Human Development Report. The World Bank, Washington, D.C. 